\title{
PERTANGGUNGJAWABAN HUKUM PENGANGKUTAN TERHADAP PENUMPANG DAN BARANG ANGKUTAN DISEBABKAN KELALAIAN
}

Putra Halomoan HSB

Fakultas Syariah dan Ilmu Hukum IAIN Padangsidimpuan

E-mail: putrahsb.halomoan@gmail.com

\begin{abstract}
Legal accountability transportation to passengers and goods transport and compensation caused forgetfulness: this article talk about scope transportation including definition transportation, object and the transportation, the types of transportation the nature and the purpose of transportation and relation to passengers and goods transport, as well as to discuss sanction loss. And accountability transportation when damage occurs and loss of goods passengers who caused forgetfulness the carrier, and limits the boundaries that included in responsibility transportation. Where there are several the types of accountability who carried out by the carrier the accountability transportation seen from error and neglect, accountability because presumption and accountability absolute. Next talking about rights and obligations the parties.
\end{abstract}

Keywords :Legal Accountability, Passenger Transportation, Negligence.

Artikel ini membahas tentang ruang lingkup pengangkutan termasuk definisi pengangkutan, objek dan pihak pengangkutan, jenis-jenis pengangkutan sifat dan tujuan pengangkutan serta kaitannya dengan penumpang dan barang angkutan, serta membahas tentang sanksi kerugian. Serta pertanggungjawaban pengangkutan ketika terjadi kerusakan serta kehilangan barang penumpang yang disebabkan kelalaian pihak pengangkut, dan batasan batasan yang termasuk dalam tanggungjawab pengangkutan. Dimana terdapat beberapa jenis-jenis pertanggungjawaban yang dilakukan oleh pihak pengangkut yakni pertanggungjawaban pengangkutan dilihat darikesalahan dankelalaian, pertanggungjawaban karena praduga dan pertanggungjawaban mutlak. Selanjutnya berbicara tentang hak dan kewajiban para pihak.

Kata Kunci: Pertanggungjawaban Hukum, Pengangkutan Penumpang, Kelalaian. 


\section{A. Pendahuluan}

Pengangkutan

merupakan suatu jasa dalam pemindahan barang ataupun orang dari suatu tempat ke tempat yang lain dengan mempergunakan alat angkutan melalui darat, laut maupun udara. Dalam hal pengangkutan barang, pengangkutan dapat diartikan yaitu memindahkan barang-barang produksi dan barang perdagangan ke tempat konsumen dan sebaliknya bagi para produsen pengangkutan barang pengangkut barang memungkinkan mereka memperoleh bahan-bahan yang mereka perlukan untuk memproduksi barang.

Mengenaidefenisipengangkutan secara umum dalam Kitab UndangUndang Hukum Dagang (KUHD) tidak ada, yang ada hanya mengenai pengangkutan laut yang dinyatakan dalam Pasal 466 KUHD dikatakan bahwa :

"Pengangkutan dalam arti bab ini ialah barang siapa yang baik dengan perjanjian carter menurut waktu atau carter menurut perjalanan, baik dengan perjanjian lainnya mengikatkan dii untuk menyelenggarakan pengangkutan barang yang seluruhnya barang atau sebagian melalui lautan."

${ }^{1}$ R. Subekti, dkk, Kitab UndangUndang hukum Dagang, PT Pradnya Paramita,Jakarta,Cetakan 27,2002, hlm 134
Kemudian Pasal 521 KUHD menyatakan :

"Pengangkutan dalam arti bab ini adalah barang siapa yang baik dengan carter menurut waktu atau carter menurut perjalanan baik dengan perjanjian lain mengikatkan dirinya untuk menyelenggarakan pengangkutan orang (penumpang) seluruhnya atau sebagian melalui lautan." 2

Dari dua defenisi yang dikemukakan dalam Pasal 466 KUHD tersebut dapat diartikan secara umum bahwa pengangkutan adalah: Barang siapa yang melakukan penawaran umum bagi siapa saja untuk menyelenggarakan pengangkutan sehingga ia wajib memenuhi permintaan atau tidak menolak untuk mengangkut. Kata barang siapa dalam ketentuan ini dapat berupa orang pribadi atau badan hukum yang mengikatkan diri dalam pelaksanaan pengangkutan. Pelaksanaan pengangkutan ini haruslah ada persetujuan terlebih dahulu dan ada kesepakatan diantara pihak yang bersangkutan, dan tidak terlepas dengan syarat-syarat perjanjian yang ada dalam Kitab Undang-Undang Hukum Perdata ( KUHPerdata).

Menurut Sution Usma Adji, bahwa pengangkutan adalah:

${ }^{2} \mathrm{Ibid}$ 
"Sebuah perjanjian timbal balik, dimana pihak pengangkut mengikatkan diri untuk menyelenggarakan pengangkutan barang atau orang dari tempat tujuan tertentu, sedangkan pihak lainnya (pengirim atau penerima) berkeharusan memberikan pembayaran biaya tertentu untuk pengangkutan tersebut."3

Sedangkan Purwosutjipto, berpendapat bahwa : Pengangkutan adalah perjanjian timbal balik antara pengangkut dengan pengiriman, dimana pengangkut mengikatkan diri untuk menyelenggarakan pengangkutan barang dan atau orang dari suatu tempat ke tempat tujuan tertentu dengan selamat, sedangkan pihak pengirim mengikatkan diri untuk membayar uang angkutan. ${ }^{4}$

$$
\text { Selanjutnya menurut }
$$

Soekardono, bahwa perjanjian pengangkutan itu adalah: "Sebuah perjanjian timbal balik, dimana pihak pengangkut mengikatkan diri untuk menyelenggarakan pengangkutan ke tempat tujuan tertentu, sedangkan pihak lain, berkewajiban untuk

${ }^{3}$ Sutiono UsmanAdji, dkk, "Hukum Pengangkutan Di Indonesia",Penerbit Rineka Citra, Bandung,1990, hlm 6

${ }^{4}$ H.M.N Purwosutjipto,"Pengertian Pokok Hukum Daang Indonesia", Jilid 3, Hukum Pengangkutan, Penerbit Djambatan, Jakarta, 1981, hlm 2 membayar biaya tertentu pekerjaan pengangkutan itu."

Sebelum

pengangkutan

dilaksanakan pada umumnya terjadi suatu perjanjian antara pihak pengangkut dengan pihak pengirim barang. Perjanjian pengangkutan pada pembahasan ini adalah perjanjian pengangkutan darat dengan menggunakan kenderaan bermotor berupa bus yang pada dasarnya sama dengan perjanjian pada umumnya. Artinya untuk sahnya suatu perjanjian haruslah memenuhi syarat-syarat yang diatur dalam Pasal 1320 KUHPerdata dan Pasal 1338 KUHPerdata tentang mengikatnya suatu perjanjian. Menurut Pasal 1320 KUHPerdata syarat sahnya suatu perjanjian adalah:

1. Kesepakatan mereka yang mengikatkan diri.

2. Kecakapan untuk membuat suatu perjanjian.

3. Suatu hal tertentu.

4. Suatu sebab yang halal.

Kemudian Pasal 1388

KUHPerdata menyatakan :

1. Semua perjanjian yang dibuat secara sah berlaku sebagai undang-undang bagi mereka yang membuatnya.

${ }^{5}$ Soekardono,Pengertian Pokok Hukum Dagang Indonesia, Penerbit soereong, Jakarta, 1981, hlm 2 
2. Perjanjian-perjanjian itu tidak dapat ditarik kembali selain dengan sepakat kedua belah pihak.

3. Perjanjian harus dilaksanakan dengan i'tikad baik.

Pihak-pihak yang mengadakan perjanjian di sini adalah pihak pengangkut dengan pengiriman barang. Jadi, dapat dikatakan bahwa perjanjian pengangkutan pada dasarnya sama dengan perjanjian pada umumnya, dimana ketentuan dasarnya seperti yang telah disebutkan di atas.

Sebelum penulis menguraikan lebih lanjut mengenai jenis-jenis pengangkutan, ada baiknya penulis akan menjelaskan tentang perjanjian pengangkutan yaitu perjanjian pengangkutan yang dilakukan para pihak sebelum melakukan pengangkutan dan perjanjian yang dilakukan berupa perjanjian pengangkutan pada umumnya yang bersifat tidak tetap atau disebut dengan pelayanan berkala. Artinya dalam melaksanakan perjanjian pengangkutan tidak terus menerus, tetapi hanya kadangkala, kalau pengirim membutuhkan pengangkutan untuk mengirimkan barang. ${ }^{6}$

${ }^{6}$ Mr. R. Soekardono, Hukum “Dagang Indonesia” PenerbitSoeroeng,Jakarta,1961,hlm 10
Perjanjian yang bersifat pelayanan berkala ini terdapat pada Pasal 1601 KUHPerdata yaitu pada bagian ketentuan umum.

\section{B. Jenis-Jenis Pengangkutan}

Pengangkutan sebagai sarana untuk mempermudah sampainya seseorang atau barang di suatu tempat dan dilakukan dengan berbagai cara dan dengan menempuh perjalanan yang berbeda. Ada yang melalui darat, laut maupun udara. Dimana pengangkutan itu berfungsi untuk memindahkan barang atau orang dari suatu tempat ke tempat lain dengan maksud untuk meningkatkan daya guna dan nilai dari barang tersebut. ${ }^{\text {? }}$

Dalam pembahasan ini penulis akan menguraikan jenis-jenis pengangkutan yang dikenal pada umumnya. Dimana pengangkutan yang sering digunakan di dalam dunia pengangkutan terbagi atas 3 jenis pengangkutan yaitu :

1. Pengangkutan Darat

2. Pengangkutan Udara

3. Pengangkutan di Perairan

Dalam pelaksanaannya seharihari oranglebih banyak menggunakan pengangkutan melalui darat terutama bagi pedagang yang akan menjual barang dagangannya ke daerah lain, karena ongkos pengangkutan pada pengangkutan darat lebih

${ }^{7}$ Sutiono Usman Adji,dkk, Op-Cit hlm 9 
murah jika dibandingkan dengan pengangkutan pengangkutan udara dan pengangkutan laut.

\section{Objek dan Pihak Dalam Pengangkutan}

Sebagaimana yang telah diuraikan pada pembahasan sebelumnya bahwa pengangkutan adalah : perjanjian timbal balik pengangkut dengan pengirim, dimana pengangkut mengikatkan diri untuk menyelenggarakan pengangkutan barang atau orang dari suatu tempat ke tempat tujuan tertentu dengan selamat, sedangkan pihak pengirim mengikatkan diri untuk membayar uang angkutan.

Agar terlaksananya pengangkutan tersebut dengan baik sesuai dengan tujuannya, maka sebelum dilaksanakan pengangkutan itu harus diadakan perjanjian antara pihak pengangkut dengan pihak pengirim barang. Dalam melaksanakan perjanjian pengangkutan harus ada objek dari pengangkutan itu sendiri dimana objek pengangkutan itu antara lain :

\section{a. Pengangkutan Barang}

Dalam hal pengangkutan barang yang menjadi objek pengangkutan adalah "barang". Barang yang dimaksud di sini adalah barang yang sah dan dilindungi oleh undangundang. Dalam pengangkutan darat dengan kenderaan bermotor berupa bus jenis barang muatan yang dapat diangkut berupa :

1. Barang sandang, seperti kain dan baju.

2. Barang pangan seperti beras, gula dan buah-buahan.

c. Barang rumah tangga seperti lemari dan alat-alat dapur.

Dalam menyelenggarakan pengangkutan dari suatu tempat ke tempat tujuan tertentu. Kedua belah pihak mempunyai kewajiban masingmasing yaitu :

1. Pihak pengangkut mempuyai kewajiban untuk mengangkut barang ataupun orang dari suatu ke tempat lain dengan selamat.

2. Pihak pengirim berkewajiban membayar ongkos yang disepakati serta menyerahkan barang tersebut diserah terimakankepadapenerimayang mana alamatnya tercantumnya dalam surat angkutan.

Sewaktu perjanjian pengangkutan barang diadakan pihak pengangkutan membuat suatu akta yang dinamakan dengan surat muatan. Dimana dalam surat muatan tersebut memuat hak-hak sebagai berikut :

1. Nama barang, berat ukuran bilangan dari jumlah ongkos perpotong dan per kilogram. 
2. Nama orang penerima kepada siapa barang itu diserahkan.

3. Jumlah upah pengangkut, tanda tangan pengirim dan surat angkutan itu harus dicatat dalam buku register.

4. Surat muatan tersebutlah yang merupakan perjanjian antara pengangkut dan pengirim, akan tetapi surat muatan itu tidak mengikat pengangkut jika tidak ditanda tanganioleh pengangkut dan pengirim barang.

b. Pengangkutan Orang

Berbeda dengan pengangkutan barang, maka yang menjadi objek dalam perjanjian pengangkutan orang adalah orang. Dalam hal perjanjian pengangkutan orang, penyerahan kepada pengangkut tidak ada. Tugas pengangkut hanya membawa atau mengangkut orang sampai di tempat tujuan dengan selamat, dan tentang barang yang dibawa oleh pihak penumpang tidak termasuk dalam barang angkutan akan tetapi digolongkan kedalam barang bawaan. Seperti tas yang disandang serta bungkusan yang bersifat skala kecil.

Mengenai pengangkutan orang diatur dalam UULAJR yang disebutkan bahwa pengangkutan orang dengan kenderaan bermotor wajib menggunakan kenderaan bermotor untuk penumpang, dengan memakaibagasimaupun tanpabagasi.
Ketentuan ini dimaksudkan untuk menjaga keselamatan penumpang dan kenyamanan penumpang.

Dalam rangka menjamin kelangsungan pelayanan angkutan, keseragaman dan keteraturan dalam pemberian pelayanan, ditentukan pelayanan wilayah kota yang didasarkan pada sifat dan ketentuan perjalanan, jarak dan waktu tempuh berkembang suatu daerah atau kawasan menjadi kawasan pemukiman, perdagangan, industri perkantoran dan sebagainya.

Pengertian trayek tetap teratur adalah pelayanan angkutan yang dilakukan dalam jaringan trayek secara tetap dan teratur, dengan jadwal tetap atau tidak terjadwal. Sedangkan pengertian tidak tetap dalam trayek ini adalah pelayanan angkutan yang dilakukan dengan tidak terikat dalam jaringan trayek tertentu dengan jadwal pengangkutan yang tidak teratur. ${ }^{8}$

Ketentuan tersebut dimaksudkan untuk mengendalikan pelayanan angkutan dengan kenderaan umum agar dapat dicapai keseimbangan antara kebutuhan jasa angkutan dengan penyediaan jasa angkutan, maka kapasitas jaringan transportasi jalan dengan kenderaan umum yang beroperasi, serta untuk menjamin

${ }^{8}$ HMN.Purwosutjipto,Op-Cit,hlm 29 
kualitas pelayanan angkutan penumpang.

Pihak-pihak dalam pengangkutan adalah para subjek hukum sebagai pendukung hak dan kewajiban dalam hubungan hukum pengangkutan. Wiwoho Soedjono menjelaskan bahwa di dalam pengangkutan di laut terutama mengenai pengangkutan barang, maka perlu diperhatikan adanya tiga unsur yaitu : pihak pengirim, pihak penerima barang dan barangnya itu sendiri. ${ }^{9}$

Perjanjian pengangkutan barang para pihak yang terkait bisa terdiri dari :

1. Pihak pengangkut (penyedia jasa pengangkutan), yaitu pihak yang berkewajiban memberikan pelayanan jasa angkutan, barang dan berhak atas penerimaan pembayaran tarif angkutan seperti yang telah diperjanjikan.

2. Pihak pengirim barang (pengguna jasa angkutan), yaitu pihak yang berkewajiban untuk membayar tarif (ongkos) angkutan sesuai yang telah disepakati dan berhak memperoleh jasa pelayanan angkutan atas barang yang dikirimnya.

${ }^{9}$ Wiwoho Soejono, "Hukum Pengangkutan Indonesia”, Semarang,1999, hlm 28
3. Pihak penerima barang (pengguna jasa angkutan), yaitu sama dengan pihak pengirim, namun adakalanya pihak pengirim barang juga adalah sebagai pihak yang menerima barang yang diangkut di tempat tujuan.

Sedangkan dalam hal perjanjian pengangkutan penumpang, maka pihak yang terkait adalah :

1. Pihak pengangkut (penyedia jasa angkutan) yaitu pihak yang berkewajiban memberikan pelayanan jasa angkutan penumpang dan berhak atas penerimaan pembayaran tarif (ongkos) angkutan sesuai yang telah ditetapkan.

2. Pihak penumpang (pengguna jasa angkutan), yaitu pihak yang berhak mendapatkan pelayanan jasa angkutan penumpang dan berkewajiban untuk membayar tarif (ongkos) angkutan sesuai yang telah ditetapkan.

\section{Fungsi dan Sifat Pengang- kutan}

Menurut HMN Purwosutjipto, fungsi pengangkutan adalah memindahkan barang atau orang dari suatu tempat ke tempat yang lain dengan maksud untuk meningkatkan daya guna dan nilai. ${ }^{10}$

\footnotetext{
${ }^{10} \mathrm{HMN}$ Purwosutjipto,Op-Cit, Hlm 12
} 
Mengenai fungsi pengangkutan adalah sangat penting sekali dalam kehidupan masyarakat, terutama dalam dunia perdagangan, mengingat kegiatan pengangkutan merupakan sarana untuk memindahkan barang dari produsen ke agen atau grosir dan selanjutnya sampai ke konsumen dalam hal angkutan barang. Sedangkan untuk pengangkutan penumpang (orang), maka kegiatan pengangkutan berfungsi untuk memindahkan penumpang (orang) dari suatu tempat ke tempat lain yang menjadi tujuannya. Dengan jasa kegiatan pengangkutan tersebutlah barang atau penumpang dapat berpindah dari tempat asal ke tempat tujuan.

Fungsi pengangkutan itu adalah dengan dilakukannya kegiatan pengangkutan itu maka barang atau benda yang diangkut itu akan meningkatkan daya guna maupun nilai ekonomisnya. Misalnya hasil bumi berupa sayur-mayur dari Tanah Karo apabila telah diangkut ke kota Medan atau diekspor ke berbagai manca negara dengan jasa pengangkutan maka nilai guna dan nilai ekonomis dari sayurmayur tersebut akan meningkat. ${ }^{11}$ Sedangkan untuk pengangkutan penumpang (orang), maka kegiatan-

${ }^{11}$ Hasim Purba, Hukum Pengangkutan di Laut, penerbit Pustaka Bangsa Prees, Medan, 2005, hlm 135 kegiatan pengangkutan juga akan membawa fungsi bagi penumpang sebagai pengguna jasa angkutan. Artinya dengan dukungan jasa angkutan tersebut penumpang dapat sampai ke tempat yang dituju untuk selanjutnya melakukan kegiatan yang dia maksudkan.

Sifat-sifat pengangkutan menurut Pasal 1601 - Pasal 1604 KUHPerdata. Dapat dikemukakan bahwa pemborongan itu menurut redaksi Pasal 1601 sendiri, pihak pemborong harus menciptakan sesuatu tertentu (een bepaald werks tot stand to brengen) bagi pihak yang memborongkan (aanbesteder), jadi sebuah benda baru (gedung, terusan, jalan kereta api, dan sebagainya) yang tadinya belum ada, kenyataannya sukar dapat dipergunakan pada pengangkutan, sama sekali tidak diperjanjikan perwujudan benda baru, melainkan pengangkut yang baik akan sekeras-kerasnya berusaha, supaya benda-benda muatan yang dipercayakan kepadanya secara utuh dan lengkap, tak berubah (tidak rusak atau berkurang) sampai di tempat tujuan.

Di dalam Code Civil di Perancis dengan tegas diperbedakan antara perjanjian pengangkutan dan pemborongan, bahwa mengenai perjanjian pengangkutan barang dan orang diatur sendiri di dalam Code Civil tersebut, yaitu dalam Pasal 
1782-1786, kemudian pasal tersebut dilakukan perubahan dioper ke dalam W.v.K. di Belanda, Pasal 91 dan seterusnya (sama dengan Pasal 91 di dalam KUHD sekarang), jadi tidak dioper di dalam B.W. di Nederland. ${ }^{12}$

Teranglah bahwa pengangkutan barang atau orang merupakan pekerjaan tertentu yang harus dipenuhi terhadap pihak yang memerlukan akan pekerjaan itu dengan pemberian upah. Pekerjaan tersebut dilakukan pada waktu-waktu yang diperlukan, walaupun apabila pengangkut menunaikan prestasinya secara baik, yang membutuhkan pengangkutan mungkin akan tetap memakai perusahaan pengangkutan tertentu yang kenamaan.

Pada umumnya hubungan hukum antara pengangkut dengan pihak yang memakainya itu adalah bermacam-macam yaitu sama tinggi, sama rendah atau kedua belah pihak adalah "gecoordineerd". Tidak ada imbangan majikan terhadap buruh atau imbangan "gesubordineerd" pada hubungan hukum antara pemakai pengangkutan dan pengangkut. Karena itu sifat perjanjian pengangkutan adalah sebuah perjanjian untuk melakukan pelayanan (jasa) berkala (een overeenkomstot het verrichten van enkele diensten), Sesuai dengan Pasal 1601

${ }^{12}$ Sutiono Usman Adji,dkk, Op-cit, hlm
KUHPerdata. Dalam bahasan ini ini sifat dari pengangkutan memidahkan barangdaritempatyangsatu ketempat lain dan mengharapkan upah dari usahanya tersebut, dan proses yang dilakukan secara berkala tidak seperti majikan dan pembantu yang secara terus-menerus.

\section{E. Tanggung Jawab Dalam Hukum Pengangkutan}

Pengusaha pengangkutan bertanggung jawab atas keselamatan barang,kelambatan datangnyabarang, kerusakan dan kehilangan barang yang diangkut dengan demikian posisi pengusaha pengangkutan sama dengan pengangkutan yang dimaksud dan Pasal 91 KUHD yang berbunyi : "Pengangkut harus menanggung segala kerusakan yang terjadi pada barang-barang angkutan lainnya setelah barang itu mereka terima untuk diangkut, kecuali kerusakankerusakan yang diakibatkan karena suatu cacat pada barang itu sendiri karena keadaan yang memaksa atau karena kesalahan atau kelupaan si pengirim". ${ }^{13}$

Tanggung jawab dalam hukun pengangkutan diatur dalam Pasal 1236 KUHPerdata menyatakan : Pengangkut wajib mengganti biaya, rugi dan bunga yang layak harus diterima bila ia tidak menyerahkan atau tidak merawat sepantasnya

${ }^{13}$ KUHPerdata, Op-Cit 
untuk menyelamatkan barang-barang angkutan.

\section{Pasal 438 ayat 3 KUHD} menyatakan : Ia bertanggung jawab atas perbuatan dari mereka, yang dikerjakannya dan untuk segala benda yang dipakainya dalam menyelenggarakan pengangkutan tersebut.

Dalam hukum pengangkutan dikenal tiga prinsip tanggung jawab yaitu : tanggung jawab karena kesalahan, tanggung jawab karena praduga, dan tanggung jawab mutlak. ${ }^{14}$

\section{Tanggung Jawab Karena Kesalahan (Foult Liability)}

Menurut prinsip ini, setiap pengangkut yang melakukan kesalahan dalam penyelenggaran pengangkutan harus bertanggung jawab membayar segala kerugian yang timbul akibat kesalahannya itu. Pihak yang menderita kerugian wajib membuktikan kesalahan pengangkut. Beban pembuktian ada pada pihak yang dirugikan bukan pada pihak pengangkut. Prinsip ini diatur dalam Pasal 1365 KUHPerdata tentang perbuatan melawan hukum sebagai aturan umum. Sedangkan aturan khusus ditentukan dalam undangundang yang mengatur masingmasing jenis pengangkutan.

${ }^{14} \mathrm{Mr}$. E Suherman, Op-Cit, Hlm 18
Pada pengangkutan dengan kenderaan bermotor, tanggung jawab ini ditentukan dalam Pasal 28 UULAJR yang menyatakan : Pengemudi kenderaan bermotor bertanggung jawab atas kerugian yang diderita oleh penumpang atau pemilik barang yang timbul karena kelalaian atau kesalahan pengemudi dalam mengemudikan kenderaan bermotor. ${ }^{15}$

Pada pengangkutan dengan kereta api tanggung jawab ditentukan dalam Pasal 28 UUKA menyatakan :

1. Badan penyelenggaran bertanggung jawab atas kerugian yang diderita oleh pengguna jasa atau pihak ketiga yang timbul dari penyelenggaraan pelayanan angkutan kereta api.

2. Tanggung jawab sebagaimana dimaksud dalam ayat 1 diberikan dengan ketentuan :

a. Sumber kerugian berasal dari pelayanan angkutan dan harus dibuktikan adanya kelalaian petugas atau pihak lain yang diperkejakan oleh badan penyelenggara.

b. Berdasarkan ganti rugi dibatasi sejumlah maksimum asuransi ditutup oleh badan penyelenggara

${ }^{15}$ Undang-Undang Nomor 14 Tahun 1992, Tentang "lalu Lintas dan Angkutan Jalan Raya" 
dalam hal penyelenggaraan kegiatannya.

Pengertian kerugian yang diderita oleh pengguna jasa tidak termasuk keuntungan yang diperoleh ataupun biaya pelayanan yang sudah dinikmati.

\section{Tanggung Jawab Karena Praduga (Presmption Liability)}

Menurut prinsip ini, pengangkut dianggap selalu bertanggung jawab atas setiap kerugian yang timbul dari pengangkut yang diselenggarakannya. Tetapi jika pengangkut dapat membuktikan bahwa dia tidak bersalah, maka dia dibebaskan dari tanggung jawab membayar ganti rugi. Yang dimaksud dengan "Tidak bersalah" adalah tidak melakukan kelalaian, telah berupaya melakukan tindakan yang perlu untuk menghindari kerugian atau peristiwa yang menimbulkan kerugian itu tidak mungkin dihindari. ${ }^{16}$ Beban pembuktian ada pada pihak pengangkut, bukan pada pihak yang dirugikan. Pihak yang dirugikan cukup menunjukkan adanya kerugian yang diderita dalam pengangkutan yang diselenggarakan oleh pengangkut.

KUHD juga menganut prinsip tanggung jawab karena praduga. Hal ini dapat dibaca dalam Pasal 468 ayat 2 KUHD yang menentukan

\footnotetext{
${ }^{16} \mathrm{Mr}$. E. Suherman, Op-Cit, hlm 23
}

bahwa barang yang diangkut itu tidak diserahkan sebagian atau seluruhnya, atau rusaknya, pengangkutan bertanggung jawab mengganti kerugian kepada pengirim kecuali jika ia dapat membuktikan bahwa tidak diserahkan sebagian atau seluruh atau rusaknya barang itu karena peristiwa yang tidak dapat dicegah atau tidak dapat dihindari.

\section{Tanggung Jawab Mutlak (Absolute Liability)}

Menurut prinsip ini, pengangkutan harus bertanggung jawab atas setiap kerugian yang timbul dalam pengangkutan yang diselenggarakannya tanpa keharusan pembuktian ada tidaknya kesalahan pengangkut.Prinsipinitidakmengenal beban pembuktian unsur kesalahan tak perlu dipersoalkan. Pengangkut tidak mungkin bebas dari tanggung jawab dengan alasan apapun yang menimbulkan kerugian itu. Prinsip ini dapat dirumuskan dengan kalimat Pengangkut bertanggung jawab atas setiap kerugian yang timbul karena peristiwa apapun dalam menyelenggarakan pengangkutan.

Dalam perundang-undangan mengenai pengangkutan, ternyata prinsip tanggung jawab mutlak diatur. Hal ini tidak diatur mungkin karena alasan bahwa pengangkut yang berusaha di bidang jasa angkutan tidak perlu dibebani 
dengan resiko yang terlalu berat. Namun tidak berarti bahwa pihakpihak tidak boleh saja menjanjikan penggunaan prinsip ini untuk kepentingan praktis penyelesaian tanggung jawab, berdasarkan asas kebebasan berkontrak. Jika prinsip ini digunakan maka di dalam perjanjian pengangkutan harus dinyatakan dengan tegas, misalnya pada dokumen pengangkutan.

Pengusaha angkutan umum bertanggung jawab atas kerugian yang diderita oleh penumpang, dan pengiriman barang karena kelalaiannya dalam melaksanakan pelayanan angkutan (Pasal 45 ayat 1) UULAJR.

Dalam pelaksanaan angkutan, keselamatan penumpang atau barang yang diangkut pada dasarnya berada dalam tanggung jawab pengusaha angkutan. ${ }^{17}$ Dengan demikian, sudah sepatutnya apabila kepada pengusaha angkutan dibebankan tanggung jawab terhadap setiap kerugian yang diderita olehpenumpangataupengirimbarang yang timbul karena pengangkutan yang dilakukannya. Dengan beban tanggung jawab ini pengangkut didorong supaya berhati-hati dalam melaksanakan pengangkutan. Untuk mengantisipasi tanggung jawab yang mungkin timbul, Pasal 46 UULAJR menentukan, pengusaha angkutan

${ }^{17} \mathrm{Mr}$. E. Suherman, Op-cit, hlm 25 wajib mengasuransikan tanggung jawabnya.

Tanggung jawab pengusaha angkutan-angkutan umum terhadap pemilik barang (pengirim) dimulai sejak barang diterima untuk diangkut sampai diserahkannya barang kepada pengirim atau penerima (Pasal 46 ayat 3 dan 4 UULAJR). Besarnya ganti rugi adalah sebesar kerugian yang secara nyata ini adalah ketentuan undangundang yang tidak boleh disimpangi oleh pengangkut melalui ketentuan perjanjian yang menguntungkannya karena ketentuan ini bersifat memaksa (dwingendrecht). Tidak termasuk dalam pengertian kerugian yang secara nyata diderita antara lain adalah :

1. Keuntungan yang diharapkan akan diperoleh.

2. Kekurangan yang diakibatkan karena kondisi jalan atau jembatan yang dilalui selama dalam perjalanan.

3. Biaya atas pelayanan yang sudah dinikmati.

Pengemudi dan pemilik kendaraan bertanggung jawab terhadap kendaraan berikut muatannya yang ditinggalkannya di jalan(Pasal24ayat2UULAJR), inidapat diartikan jika muatan penumpang atau barang yang ditinggalkannya di jalan itu menderita kerugian, maka pengemudi atau pemilik dan pemilik 
kendaraan wajib membayar ganti rugi bersama-sama secara tanggung renteng. Tetapi dalam Pasal 28 UULAJR ditemukan, pengemudilah yang bertanggungjawab ataskerugian yang diderita oleh penumpang, pemilik, pihak ketiga yang timbul karena kelalaian atau kesalahan pengemudi dalam mengemudikan kenderaan bermotor. $^{18}$

\section{F. Perjanjian Pengangkutan dan Hak serta Kewajiban Para Pihak}

Pada pokok bahasan ini penulis akan menguraikan dua konsep yaitu mengenai perjanjian pengangkutan dan konsep mengenai hak dan kewajiban para pihak pada angkutan darat.

\section{Perjanjian Pengangkutan}

Untuk menyelenggarakan pengangkutan, terlebih dahulu ada perjanjian antara pengangkut dan pengirim, Perjanjian pengangkutan adalah persetujuan dimana pengangkut mengikatkan diri untuk menyelenggarakan pengangkutan penumpang atau barang dari suatu tempat ke tempat tujuan tertentu dengan selamat dan pengirim mengikatkan diri untuk membayar biaya angkutan. ${ }^{19}$

${ }^{18}$ UULAJR,Op-Cit,hlm 34

${ }^{19}$ Abdul Kadir Muhammad, "Hukum pengangkutan Niaga", Penerbit PT Citra Aditya, Bandung, 1998, hlm 35
Perjanjian pengangkutan selalu digunakan secara lisan tetap didukung oleh dokumen pengangkutan yang membuktikan bahwa perjanjian sudah terjadi.

Dalamperjanjianpengangkutan, kedudukan para pihak yaitu pengirim dan pengangkut sama tinggi, yakni tidak seperti dalam perjanjian perburuhan, dimana para pihak tidak sama tinggi, yakni majikan mempunyai kedudukan lebih tinggi daripada buruh. Kedudukan para pihak dalam perjanjian perburuhan ini disebut kedudukan subordinasi (gesubordineerd), sedangkan kedudukan para pihak dalam perjanjian pengangkutan adalah sama tinggi atau kedudukan koordinasi (gecoordineerd).

Dalam melaksanakan perjanjian pengangkutan, hubungan kerja antara pengirim dan pengangkut tidak harus terus menerus, tetapi hanya kadang kala, kalau pengirim membutuhkan pengangkutan untuk mengirim barang. Hubungan semacam ini disebut "pelayanan berkala" sebab pelayanan ini tidak bersifat tetap, hanya kadang kala saja, bila pengirim membutuhkan pengangkutan, perjanjian berkala ini diatur dalam Pasal 1601 KUHPerdata.

Dalam undang-undang ditentukan bahwa pengangkutan baru diselenggarakan setelah biaya 
angkutan dibayar lebih dahulu. Tetapi di samping ketentuan undangundang juga berlaku kebiasaan masyarakat yang dapat membayar biaya angkutan, kemudian perjanjian pengangkutan biasanya meliputi kegiatan pengangkutan dalam artiluas yaitu kegiatan memuat, membawa dan menurunkan atau membongkar barang. Pengangkutan dalam arti luas ini erat hubungannya dengan tanggung jawab pengangkut apabila terjadi peristiwa yang menimbulkan kerugian. Artinya tanggung jawab pengangkut mulai berjalan sejak penumpang atau barang dimuat ke dalam alat pengangkut sampai barang dibongkar dari alat pengangkut atau diserahkan kepada penerima.

Tanggung jawab dapat diketahui dari kewajiban yang telah ditetapkan dalamperjanjianatauundang-undang. Kewajiban pengangkutan adalah menyelenggarakan pengangkutan. Kewajiban ini mengikat sejak penumpang atau pengirim melunasi biaya angkutan.

Apabila penumpang mengalami kecelakaan ketika naik alat pengangkut atau selama diangkut, atau ketika turun darialat pengangkut, maka pengangkut bertanggung jawab membayar segala kerugian yang timbul akibat kecelakaan yang terjadi itu. Demikian juga halnya pada pengangkutan barang, pengangkut bertanggung jawab atas segala kerugian yang timbul akibat peristiwa yang terjadi dalam proses pengangkutan sejak pemuatan sampai pembongkaran barang di tempat tujuan. Beda dengan barang bawaan yang mana barang bawaan tersebut dapat diberikan ganti kerugiannya apabila terjadi masalah. ${ }^{20}$

Barang bawaan yang dimaksud adalah barang yang ada dalam perlindungan penumpang dan barang yang berbentuk bungkusan tetapi berskala kecil dan bisa dimasukkan dalam bagasi alat pengangkutan tersebut, misalnya berupa tas genggaman bungkusan kotak yang bentuknya kecil dan sabagainya.

Tetapi tanggung jawab pengangkut ini dibatasi oleh undangundang. Dalam undang-undang ditentukan bahwa pengangkut ini bertanggung jawab terhadap segala kerugian yang timbul akibat kesalahan, kecuali :

a. Keadaan memaksa (force majeur)

b. Cacat barang itu sendiri

c. Kesalahan dan kelalaian pengirim atau pemilik barang

Menurut R. Soekardono, bahwa perjanjian pengangkutan itu adalah sebuah perjanjian timbal balik, dimana pihak pengangkut mengikatkan diri untuk menyelenggarakan pengangkutan ke tempat tujuan

${ }^{20}$ Ibid 
tertentu, pihak lainnya (pengirim) berkewajiban untuk membayar biaya tertentu untuk pengangkutan. ${ }^{21}$

\section{Sedangkan menurut}

Purwostjipto, berpendapat "bahwa perjanjian pengangkutan adalah perjanjian timbal balik antara pengangkutan dengan pengirim. Dimana pihak pengangkut mengikatkan diri untuk menyelenggarakan pengangkutan barang atau dari satu tempat ke tempat tujuan tertentu dengan selamat, sedangkan pihak pengirim mengingatkan diri untuk membayar uang angkutan." 22

Kemudian ada kelompok yang menyatakan bahwa perjanjian pengangkutan adalah suatu perjanjian untuk melakukan pekerjaan. ${ }^{23}$ Purwosutjipto berpendapat bahwa perjanjian pengangkutan adalah suatu perjanjian campuran, karena mempunyai unsur :

1. Pelayanan berkala (Pasal 1601 KUHPerdata) pemborongan pekerjaan adalah persetujuan dengan mana pihak yang satu, si pemborong mengikatkan diri untuk menyelenggarakan suatu pekerjaan bagi pihak yang lain, pihak yang memborongkan,

\footnotetext{
${ }^{21} \mathrm{Mr}$. Soekardono, Op-Cit, hlm 10

${ }^{22} \mathrm{HMN}$. Purwosutjipto, Op-Cit, hlm13

${ }^{23}$ Achmad Ichsan, Hukum Dagang LembagaSurat-SuratBarharga, Pengangkutan", Pradnya Paramita,jakarta, 1981, hlm 409
}

dengan menerima suatu harga yang ditentukan.

2. Unsur penyimpanan, adanya ketetapan dalam Pasal 468 ayat 1 KUHD yang berbunyi: "Perjanjian pengangkutan mewajibkan kelompok pengangkut untuk menjaga keselamatan barang yang diangkutnya, mulai saat diterimanya hingga saat diserahkannya barang tersebut".

3. Unsur pemberian kuasa, hal ini dapat kita lihat dalam Pasal 371 ayat 1 KUHD yang berbuyi , "Nakhoda diwajibkan selama dalam perjalanan menjaga kepentingan para pemilik muatan, mengambil tindakantindakan yang diperlukan untuk itu menghadap ke muka hakim".

Kemudian pada ayat 3 berbunyi :Dalam keadaan yang mendesak ia diperbolehkan menjual barang muatan atau sebahagian dari itu atau guna membiayai pengeluaranpengeluaran yang telah dilakukan guna kepentingan muatan tersebut, meminjam uang dengan mempertaruhkan muatan sebagai jaminan." ${ }^{24}$

Dariuraiandiatas, terlihatbahwa perjanjian pengangkutan bersifat

${ }^{24} \mathrm{HMN}$. Purwosutjipto, Opcit, hlm 9 
campuran di samping memiliki unsur melakukan pekerjaan yaitu berupa penyelenggaran pengangkutan, juga memiliki unsur penyimpangan dan pemberian kuasa.

\section{Hak dan Kewajiban Para Pihak}

Dalam setiap perjanjian, sudah tentu harus ada pihak-pihak yang mengadakan perjanjian itu. Karena tanpa adanya pihak-pihak tersebut maka perjanjian pengangkutan, apabila tidak ada pihak yang mengadakan perjanjian maka perjanjian pengangkutan tidak akan lahir.

Sebagaimana yang telah diuraikan di atas bahwa perjanjian pengangkutan adalah suatu perjanjian timbal balik antara pengangkut dengan pengiriman barang, dimana pihak pengangkut mengikatkan diri untuk membayar uang angkutan sebagaimana yang telah diperjanjikan sebelumnya.

Dari pengertian di atas, dapat diketahui bahwa pihak-pihak dalam perjanjian pengangkutan adalah "pengangkut dan pengirim". Pengangkut adalah orang yang mengikatkan dirinya untuk menyelenggarakan pengangkutan. ${ }^{25}$ Sedangkan pengirim adalah orang yang mengikatkan dirinya untuk membayar uang angkutan sebagai imbalanjasayangdilakukanoleh pihak

${ }^{25}$ Sution Usman Adji,dkk, Op-Cit, hlm 6 pengangkut dalam melaksanakan pengangkutan tersebut. ${ }^{26}$

Pengirim pada suatu perjanjian pengangkutan tidak hanya orang perorangan saja, tetapi dapat juga merupakan suatubadanyangbergerak dalam bidang pengiriman barang, dimana badan seperti ini disebut dengan "ekspeditur".Yang dimaksud dengan Ekspeditur adalah suatu badan yang pekerjaannya menyuruh orang lain untuk menyelenggarakan pengangkutan barang baik melalui darat, laut maupun udara. ${ }^{27}$

Perjanjian yang dibuat antara ekspeditur dan pengirim disebut dengan perjanjian ekspedisi, sedangkan perjanjian ekspeditur atas nama pengirim dengan pengangkut disebut perjanjian pengangkutan.

Kemudian dalam perjanjian pengangkutan ini adakalanya penerima bertindak sebagai pihak ketiga yang berkepentingan untuk itu, misalnya seseorang yang mau pindah ke tempat lain, maka yang bersangkutan tadi perlu mengadakan perjanjian pengangkutan dengan pihak yang berkecimpung di bidang pengangkutan untuk mengangkut barang-barangnya ke tempat yang dituju tadi. Di sini pemilik barang tersebut selain bertindak sebagai 
peneriman, juga bertindak sebagai pengirim.

Sedangkan kewajiban si pengirim barang adalah membayar uang angkutan sebesar yang telah diperjanjikan dalam surat muatan. Dan pembayaran uang angkutan ini juga dapat dilakukan oleh si penerima apabila belum dibayar oleh si pengirim. Ini dapat diketahui si penerima dalam surat muatan yang diterimanya, karena dalam surat muatan dicantumkan apakah uang angkutan sudah dibayar atau belum. Jika uang angkutan belum dibayar maka penerima berkewajiban untuk membayarnya sebagaimana yang ditentukan dalam surat muatan.

Jadi di dalam hal ini pihak penerima dapat menjadi pihak yang berkepentingan dalam perjanjian pengangkutan setelah ia menyatakan kehendaknya untuk menerima barang dan si penerima barang tersebut berkewajiban untuk membayar uang angkutan barang itu.

Dalam KUHD juga diatur mengenai hak dan kewajiban serta tanggung jawab dari pada pengangkut atau penyelenggara.

Hak pengangkut atau penyelenggaran pengangkutan yang ada dalam KUHD adalah :

1. Mendapatkan pembayaran atas prestasi yang dilakukan.
2. Pengangkut berhak atas suatu penggantian kerugian yang diderita karena suratmenyurat yang diperlukan untuk pengangkutan tersebut tidak diserahkan kepadanya sebagaimana mestinya. (Pasal 478 ayat $1 \mathrm{KUHD})$.

3. Pengangkut berhak menerima penggantian kerugian yang dideritanya karena pengiriman telah memberikan keterangan yang salah atau tidak lengkapnya tentang macam dan sifatnya barang tersebut, kecuali ia tahu atau sepatutnya mengetahui akan sifat dan macam-macam barang tersebut (Pasal 479 ayat 1 KUHD).

Selain adanya hak pada si pengangkut atau penyelenggaran, pengangkut juga mempunyai kewajiban dan tanggung jawab yang diatur dalam KUHD. Dimana kewajiban dan tanggung jawab pengangkut atau penyelenggaraan pengangkutan itu adalah :

1. Pengangkut wajib menjaga keselamatan barang yang diangkutnya mulai dari saat diterimanya hingga diserahkannya barang tersebut (Pasal 468 ayat 1 KUHD).

2. Pengangkut wajib mengganti kerugian yang disebabkan karena barang-barang tersebut seluruhnya atau sebahagian 
tidak dapat diserahkan dan barang tersebut rusak kecuali apabila si pengangkut dapat membuktikan bahwa tidak diserahkannya barang atau kerusakan tersebut disebabkan oleh suatu malapetaka yang tidak dapat dicegah ataupun dihindarkan atau memang cacat tersebut adalah bawaan dari barang itu atau karena kesalahan dari si pengirim (Pasal 468 ayat 2 KUHD).

3. Pengangkut wajib bertanggung jawab atas kerugian yang disebabkan karena keterlambatan penyerahan barang yang dikirimkan kecuali apabila si pengangkut dapat membuktikan bahwa keterlambatan tersebut disebabkan malapetaka yang tidak dapat dicegah ataupun dihindarkan (Pasal 447 KUHD).

Karena perjanjian pengangkutan umum, pada umumnya terjadi secara lisan dan dibuktikan dengan karcis penumpang, maka ketentuanketentuan tersebut tertulis pada karcis penumpang. Angkutan penumpang diselenggarakan oleh beberapa perusahaan angkutan umum, baik Badan Usaha Milik Negara maupun milik swasta. Ketentuan-ketentuan yang tertulis pada karcis penumpang yang mereka terbitkan jua bervariasi namun pada pokoknya berisi kewajiban dan hak-hak yang sama.

\section{H. Ganti Kerugian Terhadap Penumpang dan Barang Angkutan}

Dalam perjanjian pengangkutan barang dengan kenderaan bermotor melalui jalan raya, ada kalanya tidak terlaksana dengan baik sebagaimana yang dikehendaki oleh pihak, sehingga menimbulkan kerugian pihak tersebut.

Timbulnya kerugian tersebut dapat terjadi karena suatu keadaan atau kejadian sehingga menghalangi pengangkut untuk melaksanakan kewajiban. Kejadian tersebut misalnya karena suatu hal yang tidak dapat dipersalahkan kepada pengangkut (Overmatch atau keadaan memaksa atau force majeure).

Dalam hal ini kewajiban untuk memikul kerugian akibat dari kejadian tersebut dinamakan "resiko". Kerugian juga dapat terjadi karena cacat pada barang itu sendiri dan juga akibat dari kesalahan atau kealpaan pihak pengirim. Selain itu kerugian juga dapat ditimbulkan sebagai akibat tidak sempurnanya pelaksanaan kewajiban dari pihak pengangkut.

\begin{tabular}{llr}
\multicolumn{3}{c}{ Sebagaimana yang telah } \\
dijelaskan bahwa & kewajiban \\
pengangkut & adalah & melaksanakan
\end{tabular}
dijelaskan bahwa kewajiban pengangkut adalah melaksanakan 
pengangkutan barang mulai dari tempat pemuatan barang sampai di tempat tujuan dengan selamat serta tepat waktunya. Jika barang yang diangkut itu selamat, maka akan timbul dua hal, yaitu barangnya sampai ke tempat tujuan, tetapi rusak sebagian atau seluruhnya dan mungkin barangnya tidak sampai di tempat (musnah), mungkin disebabkan karena terbakat, dicuri orang dan lain-lain.

Masalah lain yang sering timbul dalam pengangkutan yaitu tentang waktu sampai barang di tempat tujuan tidak sesuai dengan perjanjian sebelumnya sehingga menimbulkan kerugian pada pihak yang punya barang atau pihak pengirim.

Hal-hal yang dapat digolongkan dengan kemusnahan atau kesalahan barang yang ditimbulkan di luar kesalahan atau kelalaian pihak pengangkut dalam perjanjian pengangkutan barang, adalah karena keadaan memaksa (overmatch atau force majeure), cacat pada barang itu sendiri yaitu dapat diketahui oleh pengangkut sebelum pengangkutan barang, kesalahan oleh kelalaian pengirim itu sendiri.

Pemikiran tentang overmatch (keadaan memaksa) terdapat dua aliran yaitu :

1. Aliran objektif (de objective overmacth leer) atau absolut yaitu debitur berada dalam keadaan memaksa apabila pemenuhan prestasi itu tidak mungkin dilaksanakan oleh siapapun juga atau setiap orang.

Dalam ajaran ini pikiran para sarjana tertuju pada bencana alam ataupun kecelakaan yang hebat, sehingga dalam keadaan demikian siapapun tidak dapat memeuhi prestasi, juga barang musnah atau hilang di luar perdagangan.

Dianggap sebagai keadaan memaksa. Misalnya, kenderaan bermotor yang mengangkut tersebut ditimpa longsor di tengah jalan.

2. Aliran subjektif (de subkjective overmatch leer) atau relatif, yaitu keadaan memaksa itu ada apabila debitur masih mungkin melaksanakan prestasi, tetapi praktis dengan kesukaran atau pengorbanan yang lebih besar, sehingga dalam keadaan yang demikian itu kreditur tidak dapat menuntut pelaksanaan prestasi. Misalnya putusnya jalan dan jembatan, sehingga sulit untuk mengoper barang tersebut karena biaya pengoperannya lebih mahal dari keuntungan yang diperoleh.

Terhadap penumpang selama proses angkutan berlangsung, pengemudi diberikan wewenang oleh 
Pasal 47 UULAJR untuk menurunkan penumpang dan barangyang diangkut di tempat pemberhentian terdekat, apabila membahayakan keamanan dan keselamatan angkutan.

Wewenang ini benar dapat dipertanggung jawabkan secara hukum dan kepatutan antara lain:28

a. Penumpang yang melakukan keributan atau pencurian dalam kenderaan dan sudah diperingatkan terlebih dahulu.

b. Barang yang diangkut ternyata berbahaya bagi keselamatan angkutan.

c. Barang yang dapat mengganggu penumpang karena berbau busuk.

Pengangkut lalai dalam melakukan tugasnya, maka sesuai dengan ketentuan Pasal 45 UULAJR pengusaha angkutan bertanggung jawab atas kerugian yang diderita oleh penumpang, pengirim barang, atau pihak ketiga. Tanggung jawab terhadap pemilik barang dimulai sejak barang diterima dari pengirim sampai barang diserahkan kepada penerima ditempat tujuan yang telah disepakati.Namunpegusahaangkutan umum tidak bertanggung jawab atas kerugian yang timbul apabila ia dapat membuktikan, diantaranya:

${ }^{28}$ Sinta Uli, "Pengangkutan Suatu Tinjauan Hukum Multimoda Transport, Angkutan Laut, Angkutan Udara."Penerbit USU pres 2006, Medan, 2006.
1. Peristiwa yang tidak diduga terlebih dahulu (force majeur, Pasal 1244 KHU Perdata).

2. Cacat pada barang itu sendiri.

3. Kesalahan atau kelalaian pengirim atau ekspeditur ( Pasal 91 KUHD).

Berikut diatas merupakan hal yang perlu diperhatikan penumpang maupun pengirim barang dalam pengangkutan dan tanggung jawab pengusaha pengangkutan dalam malaksanakan tugasnya baik terhadap penumpang maupun barang angkutan.

\section{Penutup}

Pengangkutan yang merupakan suatu jasa dalam pemindahan barang ataupun orang dari suatu tempat ke tempat yang lain dengan mempergunakan alat angkutan melalui darat, laut maupun udara. Dalam hal pengangkutan barang, pengangkutan dapat diartikan yaitu memindahkan barang-barang produksi dan barang perdagangan ke tempat konsumen dan sebaliknya bagi para produsen pengangkutan barang pengangkut barang memungkinkan mereka memperoleh bahan-bahan yang mereka perlukan untuk memproduksi barang. Selanjutnya dalam traksaksi tersebut tentunya terjadi bebarapa kesalahan dan kelalaian yang dilakukan oleh pihak pengangkut, hal ini ada bebrapa 
pertanggungjwaban yang di lakukan diantaranya tanggungjawab karena kesalahan yakni pertanggungjawaban yang diberikan akibat dari pembuktian bahwa pihak pengangkut telah melakukan kesalahan, selanjutnya tanggungjawab karena praduga, pengangkut kerap dianggap salah namun ketika dapat membuktikan bahwa kesalahan bukan bersal dari pihak pengangkun maka beban tanggung jawab dibebaskan, serta tanggung jawab mutlak yakni tanpa dibuktikan terlebih dahulupun pihak pengangkut tetap salah dan wajib bertanggungjawab atas keruagian yang terjadi. 


\section{Daftar Pustaka}

Abdul Kadir Muhammad, "Hukum pengangkutan Niaga”, Penerbit PT Citra Aditya, Bandung, 1998.

Achmad Ichsan, Hukum Dagang Lembaga Surat-Surat Barharga, Pengangkutan”, Pradnya Paramita,jakarta, 1981.

Emmy Pangaribuan Simanjuntak," Hukum Dagang dan SuratSurat Berharga" Penerbit Seksi Hukum Dagang FH UGM, Yokyakarta, 1993.

Hasim Purba, Hukum Pengangkutan di Laut, penerbit Pustaka Bangsa Prees, Medan, 2005.

H.M.N Purwosutjipto,"Pengertian Pokok Hukum Dagang Indonesia", Jilid 3, Hukum Pengangkutan, Penerbit Djambatan, Jakarta, 1981.

Mr. R. Soekardono, Hukum "Dagang Indonesia" Penerbit Soeroeng, Jakarta, 1961.
R. Subekti, dkk, KitabUndang-Undang hukum Dagang, PT Pradnya paramita,Jakarta, Cetakan 27,2002 .

Sinta Uli, "Pengangkutan Suatu Tinjauan Hukum Multimoda Transport, Angkutan Laut, Angkutan Udara."Penerbit USU pres 2006, Medan, 2006

Sutiono UsmanAdji, dkk, "Hukum Pengangkutan Di Indonesia”,Penerbit Rineka Citra, Bandung, 1990.

Soekardono,Pengertian Pokok Hukum Dagang Indonesia, Penerbit soereong, Jakarta, 1981.

Undang-Undang Nomor 14 Tahun 1992, Tentang "lalu Lintas dan Angkutan Jalan Raya”

Wiwoho Soejono, "Hukum Pengangkutan Indonesia"Citra Aditya, Semarang,1999. 